\title{
Effect of Seed Priming on Seed Germination and Seedling Growth of Modern Rice (Oryza sativa L.) Varieties
}

\author{
A. A. Mamun ${ }^{1} *$ U. A. Naher ${ }^{2}$ and M. Y. Ali $^{3}$ \\ ${ }^{1}$ Seed Marketing Division, Bangladesh Agricultural Development Corporation, Gazipur \\ ${ }^{2}$ Soil Science Division, Bangladesh Rice Research Institute, Gazipur, Bangladesh \\ ${ }^{3}$ Agrotechnology Discipline, Khulna University, Khulna, Bangladesh \\ *Corresponding author and Email: mamunabdullah123@gmail.com
}

Received: 03 May $2018 \quad$ Accepted: 23 June 2018

\begin{abstract}
The experiment was carried out in the Seed Laboratory of Bangladesh Agricultural Development Corporation (BADC), Gazipur during June to July 2014 to investigate the effects of different priming methods on seed germination and the seedling growth of some rice (Oryza sativa L.) varieties. Four rice varieties: 1) Nerica, 2) BRRI dhan51, 3) BRRI dhan41 and 4) BRRI dhan49; and six priming treatments: 1) On-farm Priming, 2) Hardening, 3) Hydro-priming, 4) Osmo-hardening, 5) Vitamin C Priming and 6) Control were used in the experiment. The experiment was laid out in a completely randomized design (CRD). The treatments were replicated three times. The germination percentage and seedling growth parameters differed significantly among the priming treatments. For germination, Nerica variety showed poor performance, whereas the other varieties were found superior. Among the priming treatments, Vitamin $\mathrm{C}$ priming and Osmo-hardening were found superior. In case of interaction, germination was increased with Vitamin $\mathrm{C}$ priming and Osmo-hardening in Nerica. For seedling growth parameters, particularly vigor index, shoot and root lengths, BRRI dhan41 and BRRI dhan51 were found superior. The priming treatment Vitamin $\mathrm{C}$ and Osmo-hardening performed better than others. Seedling vigor index was increased with Vitamin $\mathrm{C}$ priming and Osmo-hardening in Nerica variety. Shoot length at $15^{\text {th }}$ day was influenced by hydro-priming in Nerica. Root length at $10^{\text {th }}$ day was significantly increased with hardening in BRRI dhan41. Vitamin C priming and Osmohardening could therefore, be used for improving germination and seedling growth of Nerica.
\end{abstract}

Keywords: Priming, Variety, Germination, Seedling growth parameters.

\section{Introduction}

Seed priming is one of the techniques to obtain higher yield of rice by producing quality seedlings. Priming is a method that might improve seed performance under the stress conditions such as drought or freshly harvested or aged seeds which might fail to germinate (Binang et al., 2012).
Good seed germination is very important for rice (Oryza sativa L.). Uneven or poor germination and subsequently uneven seedling growth can lead to great financial losses by reducing crop, though seed priming can increase speed and uniformity of germination (Ghiyasi et al., 2008). Seed priming treatments can lead to better germination and establishment in many field 
crops, such as maize, wheat, and rice. In another way seed priming could be defined as controlling the hydration level within seeds so that the metabolic activity necessary for germination can occur but radical emergence is prevented. Different physiological activities within the seed occur at different moisture levels (Taylor et al., 1998). The last physiological activity in the germination process is radical emergence. The initiation of radical emergence requires high seed water content. Once sown, seeds spend significant amounts of time just for absorbing water from the soil. By reducing this time to a minimum, seeds can be made to germinate and seedlings emerge within shorter time.

It has been reported that primed crop seeds emerged faster and grew more vigorously. They also flowered earlier, matured earlier and gave higher yields, which is very important for drought-prone areas. Priming has, therefore, become very popular and it is simple and cheap, yet extremely effective (Broud et al., 2006). Several different priming methods have been reported to be used commercially. Among them, liquid or osmotic priming is a very common practice. It is well established that seed soaking in chemical improves the crop performance over control, particularly under adverse conditions. Many workers have studied the effect of seed treatment with different chemicals and found that crops yield can be increased through pre sowing treatments with chemicals. One of the primary benefits of priming has been the extension of the temperature range at which a seed can germinate. In upland rice, Harris et al. (1999) demonstrated that on-farm seed priming markedly improved establishment and early vigor of seedlings, resulting in faster development, earlier flowering and maturity and higher yields, while Farooq et al. (2006) observed improved emergence, yield and quality of direct-seeded rice. Mondal et al. (2011) postulated that the positive effect of rice seed priming was associated with an increase in endospermic amylase activity resulting from the increase insoluble sugar content of the primed seed. Invariably, the best priming method would depend on the type of stress the seed is exposed to (Yadav et al., 2011), as well as the genotype (Berchie et al., 2010).

The other benefit of priming is to increase the rate of germination at any particular temperature. On a practical level, primed seeds emerge from the soil faster and often more uniformly than non-primed seeds because of limited adverse environmental exposure. Priming accomplishes this important development by shortening the lag or metabolic phase in the germination process. The metabolic phase occurs just after seeds are fully imbibed and just prior to radical emergence. Since seeds have already gone through this phase during priming, germination times in the field can be reduced by approximately $50 \%$ upon subsequent rehydration. Moreover priming has been commercially used to eliminate or greatly reduce the amount of seed-borne fungi and bacteria. In this framework, we have mentioned the following priming techniques- On-farm priming, Hardening, Hydro-priming, Osmo-hardening, Vitamin C (Ascorbate) priming and Control.

However, methods for priming suitable for rice have not yet been developed in Bangladesh. Moreover, there is a limited study in the country on seed priming of high yielding modern rice varieties. The present study was therefore, undertaken to examine the efficiency of different priming methods on rice seed germination, seedling growth and to determine the varietal response of rice to seed germination and seedling growth against different priming agents.

\section{Materials and Methods}

The details of materials used and methods employed during the experimental period have been presented in this chapter.

\subsection{Design and treatments of the experiment}

The experiment was conducted with two factors following completely randomized design.

Treatments were as follows:

Factor A: Priming treatments: 
a) On-farm Priming (Seeds will be soaked overnight in water before sowing) (Harries et al.,1999)

b) Hardening (Alternate soaking of seeds with tap water for 24 hours and dying before sowing in the field) (Basra et al., 2003)

c) Hydro-priming (Seeds will be soaked with distilled water for 48 hours and dried under shade before sowing in the field)

d)Osmo-hardening (Similar to hardening with 1 mole $\mathrm{NaCl}$ solution')

e) Vitamin C Priming (Seeds will be soaked with $10 \mathrm{ppm}$ Ascorbic acid solution for $48 \mathrm{hr}$ then dried 24 hours under shade) (Basra et al., 2006)

f) Control (Farmer Practice)

Factor B: Rice varieties:
a) Nerica
b) BRRI dhan 41
c) BRRI dhan 51
d) BRRI dhan49

\subsection{Preparation of chemical solution}

Chemical solutions, $\mathrm{NaCl} 58.44$ gm and Ascorbic acid $0.01 \mathrm{gm}$ of chemicals were added with $1000 \mathrm{ml}$ water.

\subsection{Preparation of germination media}

Wet tissue was used as germination media and Petridis was used as container. The moisture content of the media was maintained at $80 \%$ of the field capacity.

\subsection{Seed quality parameters}

The following seed quality parameters were measured:

\subsection{Germination}

Germination test is most commonly used to determine seed viability. The germination test was conducted at $25^{\circ} \mathrm{C}$ temperature in germination room of Seed Laboratory, Bangladesh Agricultural Development Corporation (BADC), Gazipur. One hundred seeds were taken from each pot and placed in the Petridish. The daily record of germinated seed was taken up to 7th day from set up of the test.
The germination percentage was calculated as follows:

Germination $(\%)=$

$\frac{\text { Number of seed germinated }}{\text { Total Number of seeds for test }} \times 100$

\subsection{Speed of germination}

The speed of germination (\%) was calculated by using the following formula (Krishnaswamy and Seshu, 1990).

Speed of germination $(\%)=$

Number of zeed germinated at $72 \mathrm{~h}$

Number of seeds germinated at $16 \mathrm{~g} \mathrm{~h}$

\subsection{Germination energy}

Germination energy was expressed as percentage of seeds germinated at 72 hours (Bam et al., 2006).

\subsection{Vigor index}

Seed vigor index is the sum total of all attributes of seeds which indicates the potential level and activity of seed during germination and seedling emergence. Daily count of germination of seed was taken to calculate data on vigor index. It can be calculated by the following formula (Maguire, 1962).

Vigor Index $=\frac{x_{1}}{n 1}+\frac{x_{2}}{n_{2}}+\ldots \ldots \ldots \ldots \ldots+\frac{x n}{n n}$

Where,

$\mathrm{x}_{1}=$ number of seedlings at first count

$\mathrm{n}_{1}=$ number of days at first count

$\mathrm{x}_{\mathbf{2}}=$ number of seedlings at second count

$\mathrm{n}=$ number of days at second count

$\mathrm{x}_{\mathrm{n}}=$ number of seedlings at final count

$\mathrm{n}=$ number of days at final count

\subsection{Seedlings shoot and root length}

Randomly selected 10 normal seedlings from each petridish were taken to record data on shoot and root length. It was recorded at 10 and 15 th day.

\subsection{Seedlings shoot and root dry weight}

The seedlings for shoot and root length measurements were dried in an electric oven at 
$72^{\circ} \mathrm{C}$ for 48 hours. After drying the dry weight of shoot and root were recorded by an electric balance.

\subsection{Data analysis}

The data obtained from different yield components were statistically analyzed to find out the significance of the difference among the treatments. The analysis of variance (ANOVA) was performed by MSTAT-C and means of the parameters were compared using DMRTDuncan's new Multiple Range Test (Gomez and Gomez, 1984).

\section{Results and Discussion}

\subsection{Rice seed germination parameters as influenced by variety and seed priming}

There was significant effect of treatments and their interactions on seed germination parameters (Table 3). Maximum germination was occurred on $3^{\text {rd }}$ day. The seed germination $(\%)$, speed of germination $(\%)$ and germination energy $(\%)$ of different tested rice varieties were ranged from 45.1 to $99.7,86.5$ to $100.0,53.7$ to 99.7 percentages, respectively depending of priming treatments and crop varieties (Table 1, 2 and 3).

\subsection{Rice seed germination parameters as influenced by variety}

All the germination parameters due to effect of four rice varieties were presented in Table 1. Among the varieties germination percentage on $3^{\text {rd }}$ and $7^{\text {th }}$ day, speed of germination $(\%)$ and germination energy (\%) varied widely. The highest germination percentage on $3^{\text {rd }}$ and $7^{\text {th }}$ day, speed of germination (\%) and germination energy (\%) was found in BRRI dhan49 and it was $90.9,98.0,98.3$ and $96.3 \%$, respectively that was also statistically similar to BRRI dhan 41 and BRRI dhan51 compare to Nerica.

\subsection{Rice seed germination parameters as influenced by seed priming}

All the germination parameters due to effect of five priming treatments and control were presented in Table 2. Due to priming treatments, germination percentage at $3^{\text {rd }}$ and $7^{\text {th }}$ day, speed of germination $(\%)$ and germination energy $(\%)$ varied widely. The highest germination percentage on $3^{\text {rd }}$ and $7^{\text {th }}$ day, speed of germination (\%) and germination energy (\%) was found in Vitamin $\mathrm{C}$ priming and it was 91.9 $\%, 97.7 \% 98.2 \%$ and $96.0 \%$ respectively and followed by Osmo-hardening $(\mathrm{NaCl})$. Other priming treatments performed similar to the control.

\subsection{Rice seed germination parameters as influenced by interaction effect of variety and seed priming}

All the germination parameters due to interaction effect of variety and priming are presented in Table 3. There was a significant effect of treatments and their interaction on seed germination parameters. In case of germination $(\%)$, maximum germination was occurred at $3^{\text {rd }}$ day. Statistically, the highest germination (\%) was found in Nerica variety with Vitamin C priming $(88.4 \%)$ and followed by Osmohardening priming $(71.1 \%)$. On-farm priming (49.7\%), Hardening (47.8\%) and Hydro-priming (45.11\%) had similar value compared to control. Germination percentages on $3^{\text {rd }}$ day of BRRI dhan51, BRRI dhan41 and BRRI dhan49 varieties were also maximum with Osmohardening and Vitamin $\mathrm{C}$ priming but, there were no statistical difference compared to control. In a laboratory study, it was revealed that priming with Ascorbate at various (10-50 ppm) concentrations improved the germination and early seedling growth in both coarse and fine rice varieties, although priming with $10 \mathrm{ppm}$ was the most effective (Basra et al., 2006).

Germination percentage on $7^{\text {th }}$ day for different treatments were followed similar pattern of $3^{\text {rd }}$ day irrespective of priming treatment. In speed of germination, the highest speed of germination was found in BRRI dhan41 (100.0\%), BRRI dhan51 (100.0\%) with Vitamin C priming and also BRRI Dhan41 (100.0\%), BRRI dhan49 $(100.0 \%)$ with Osmo-hardening priming. In germination energy, statistically, the highest germination energy (\%) was found in Nerica variety with Vitamin $\mathrm{C}$ priming $(92.7 \%)$ and 
followed by Osmo-hardening priming $(87.0 \%)$. On-farm priming $(49.7 \%)$, Hardening $(47.8 \%)$ and Hydro-priming (45.1\%) carried same value compared to control. Germination energy of BRRI dhan51, BRRI dhan41 and BRRI dhan49 varieties were found the highest with Osmohardening and Vitamin $\mathrm{C}$ priming. But, in that case, there was no statistical difference compared to control. According to Mohammadi (2009) seeds primed with sodium chloride $(\mathrm{NaCl})$ showed the highest values for germination percentage, germination energy, seedling dry weight, and height under both field and laboratory studies.

Germination ability of seed is not only genetically controlled character, but it may be affected by the different type of factors, such as moisture, temperature, light etc. So, there were large scope to vary the result by applying same treatment in time. In few cases control treatment was also performed well probably due to high quality seed, developed from almost same parent materials and proper management etc. If we consider the total effect of seed priming on germination, the results of the present study clearly showed that treatment Vitamin $\mathrm{C}$ priming and Osmo-hardening performed very well for germination percentages on $3^{\text {rd }} \& 7^{\text {th }}$ days and germination energy of Nerica variety. This result is in agreement with the statement of Basra et al. (2005) and Ghiyasi et al. (2008) who found Vitamin $\mathrm{C}$ priming can increase the speed and uniformity of germination and that lead to better germination and establishment in many field crops including rice.

Table 1. Effect of variety on rice seed germination parameters

\begin{tabular}{|c|c|c|c|c|}
\hline \multirow{2}{*}{ Variety } & \multicolumn{2}{|c|}{ Germination (\%) on } & \multirow{2}{*}{$\begin{array}{l}\text { Speed of } \\
\text { germination }(\%)\end{array}$} & \multirow{2}{*}{$\begin{array}{l}\text { Germination } \\
\text { energy }(\%)\end{array}$} \\
\hline & $3^{\text {rd }}$ day & $7^{\text {th }}$ day & & \\
\hline Nerica & $59.167 \mathrm{~b}$ & $73.44 \mathrm{~b}$ & $91.2 \mathrm{~b}$ & $67.27 \mathrm{~b}$ \\
\hline BRRI dhan51 & $88.72 \mathrm{a}$ & $94.83 \mathrm{a}$ & $98.4 \mathrm{a}$ & $93.33 \mathrm{a}$ \\
\hline BRRI dhan41 & $90.57 \mathrm{a}$ & $97.27 \mathrm{a}$ & $99 \mathrm{a}$ & $96.27 \mathrm{a}$ \\
\hline BRRI dhan49 & $90.90 \mathrm{a}$ & $98 \mathrm{a}$ & $98.3 \mathrm{a}$ & $96.33 \mathrm{a}$ \\
\hline Level of significance & $* *$ & $* *$ & $* *$ & $* *$ \\
\hline $\mathrm{CV} \%$ & 5.14 & 4.03 & 3.13 & 4.69 \\
\hline
\end{tabular}

Table 2. Effect of priming on rice seed germination parameters

\begin{tabular}{|c|c|c|c|c|}
\hline \multirow{2}{*}{ Priming } & \multicolumn{2}{|c|}{ Germination (\%) on } & \multirow{2}{*}{$\begin{array}{l}\text { Speed of } \\
\text { germination }(\%)\end{array}$} & \multirow{2}{*}{$\begin{array}{l}\text { Germination } \\
\text { energy }(\%)\end{array}$} \\
\hline & $3^{\text {rd }}$ day & $7^{\text {th }}$ day & & \\
\hline Control & $81.8 \mathrm{bc}$ & $89.3 \mathrm{~b}$ & $96.9 \mathrm{c}$ & $87.0 \mathrm{~b}$ \\
\hline On-farm priming & $77.9 \mathrm{c}$ & $85.5 \mathrm{c}$ & $97.3 \mathrm{bc}$ & $83.6 \mathrm{bc}$ \\
\hline Hardening & $79.7 \mathrm{c}$ & $89.7 \mathrm{~b}$ & $96.3 \mathrm{~d}$ & $86.9 \mathrm{~b}$ \\
\hline Hydro-priming & $75.4 \mathrm{c}$ & $86.08 \mathrm{c}$ & $94.0 \mathrm{e}$ & $81.6 \mathrm{c}$ \\
\hline $\begin{array}{l}\text { Osmo-hardening } \\
(\mathrm{NaCl})\end{array}$ & $87.3 \mathrm{ab}$ & $97.08 \mathrm{a}$ & $97.6 \mathrm{~b}$ & $94.8 \mathrm{a}$ \\
\hline $\begin{array}{l}\text { Vitamin C priming } \\
\text { (Ascorbic Acid) }\end{array}$ & $91.9 \mathrm{a}$ & $97.8 \mathrm{a}$ & $98.2 \mathrm{a}$ & $96.0 \mathrm{a}$ \\
\hline Level of significance & $* *$ & $* *$ & $* *$ & $* *$ \\
\hline $\mathrm{CV} \%$ & 5.14 & 4.03 & 3.13 & 4.69 \\
\hline
\end{tabular}

**=Significant at $1 \%$ level. Means followed by common letter(s) in a column do not differ significantly by DMRT. 
Table 3. Interaction effect of seed priming and variety on seed germination parameters of rice

\begin{tabular}{|c|c|c|c|c|c|}
\hline \multicolumn{2}{|c|}{ Interaction of treatment } & \multicolumn{2}{|c|}{ Germination (\%) on } & \multirow{2}{*}{$\begin{array}{c}\text { Speed of } \\
\text { germination } \\
(\%)\end{array}$} & \multirow{2}{*}{$\begin{array}{c}\text { Germination } \\
\text { energy }(\%)\end{array}$} \\
\hline Seed priming & Variety & $3^{\text {rd }}$ day & $7^{\text {th }}$ day & & \\
\hline \multirow[t]{4}{*}{ Control } & Nerica & $52.9 \mathrm{e}$ & $62.3 \mathrm{c}$ & 90.9 & $56.7 \mathrm{e}$ \\
\hline & BRRI dhan51 & $90.1 \mathrm{a}-\mathrm{c}$ & $97.7 \mathrm{a}$ & 99.3 & $97.0 \mathrm{a}-\mathrm{c}$ \\
\hline & BRRI dhan 41 & $91.2 \mathrm{a}-\mathrm{c}$ & $98.7 \mathrm{a}$ & 98.6 & $97.3 \mathrm{a}-\mathrm{c}$ \\
\hline & BRRI dhan49 & $91.1 \mathrm{a}-\mathrm{c}$ & $98.7 \mathrm{a}$ & 98.6 & $97.3 \mathrm{a}-\mathrm{c}$ \\
\hline \multirow[t]{4}{*}{ On-farm priming } & Nerica & $49.7 \mathrm{e}$ & $59.7 \mathrm{c}$ & 92.7 & $55.3 \mathrm{e}$ \\
\hline & BRRI dhan51 & $80.3 \mathrm{~cd}$ & $87.3 \mathrm{~b}$ & 98.9 & $86.3 \mathrm{~d}$ \\
\hline & BRRI dhan 41 & $90.7 \mathrm{a}-\mathrm{c}$ & $97.3 \mathrm{ab}$ & 99.3 & $96.7 \mathrm{a}-\mathrm{c}$ \\
\hline & BRRI dhan49 & 90.9 a-c & $97.7 \mathrm{a}$ & 98.3 & $96.0 \mathrm{a}-\mathrm{c}$ \\
\hline \multirow[t]{4}{*}{ Hardening } & Nerica & $47.8 \mathrm{e}$ & $66.67 \mathrm{c}$ & 88.2 & $58.33 \mathrm{e}$ \\
\hline & BRRI dhan51 & $89.4 \mathrm{a}-\mathrm{c}$ & $95.3 \mathrm{ab}$ & 99.6 & $95.0 \mathrm{a}-\mathrm{c}$ \\
\hline & BRRI dhan41 & $92.6 \mathrm{ab}$ & $99.3 \mathrm{a}$ & 98.7 & $98.0 \mathrm{ab}$ \\
\hline & BRRI dhan49 & $89.1 \mathrm{a}-\mathrm{c}$ & $97.3 \mathrm{ab}$ & 98.6 & $96.0 \mathrm{a}-\mathrm{c}$ \\
\hline \multirow[t]{4}{*}{ Hydro-priming } & Nerica & $45.1 \mathrm{e}$ & $62.0 \mathrm{c}$ & 86.5 & $53.7 \mathrm{e}$ \\
\hline & BRRI dhan51 & $82.3 \mathrm{bc}$ & $92.0 \mathrm{ab}$ & 94.8 & $87.3 \mathrm{~d}$ \\
\hline & BRRI dhan41 & $86.7 \mathrm{a}-\mathrm{c}$ & $94.3 \mathrm{ab}$ & 97.2 & $91.7 \mathrm{~cd}$ \\
\hline & BRRI dhan49 & $87.6 \mathrm{a}-\mathrm{c}$ & $96.0 \mathrm{ab}$ & 97.6 & $92.7 \mathrm{~b}-\mathrm{d}$ \\
\hline \multirow{4}{*}{$\begin{array}{l}\text { Osmo-hardening } \\
(\mathrm{NaCl})\end{array}$} & Nerica & $71.1 \mathrm{~d}$ & $93.7 \mathrm{ab}$ & 92.8 & $87.0 \mathrm{~d}$ \\
\hline & BRRI dhan51 & $91.2 \mathrm{a}-\mathrm{c}$ & $97.3 \mathrm{ab}$ & 97.6 & $95.0 \mathrm{a}-\mathrm{c}$ \\
\hline & BRRI dhan41 & $90.0 \mathrm{a}-\mathrm{c}$ & $97.7 \mathrm{a}$ & 100.0 & $97.7 \mathrm{a}-\mathrm{c}$ \\
\hline & BRRI dhan49 & $97.0 \mathrm{a}$ & $99.7 \mathrm{a}$ & 100.0 & $99.7 \mathrm{a}$ \\
\hline \multirow{4}{*}{$\begin{array}{l}\text { Vitamin C } \\
\text { priming (Ascorbic } \\
\text { Acid) }\end{array}$} & Nerica & $88.4 \mathrm{a}-\mathrm{c}$ & $96.3 \mathrm{ab}$ & 96.1 & $92.7 \mathrm{~b}-\mathrm{d}$ \\
\hline & BRRI dhan51 & $97.1 \mathrm{a}$ & $99.3 \mathrm{a}$ & 100.0 & $99.3 \mathrm{ab}$ \\
\hline & BRRI dhan41 & $92.3 \mathrm{ab}$ & $96.3 \mathrm{ab}$ & 100.0 & $96.3 \mathrm{a}-\mathrm{c}$ \\
\hline & BRRI dhan49 & 89.8 a-c & $99.0 \mathrm{a}$ & 96.6 & $95.7 \mathrm{a}-\mathrm{c}$ \\
\hline \multicolumn{2}{|l|}{ Level of significance } & $* *$ & $* *$ & NS & $* *$ \\
\hline \multicolumn{2}{|l|}{$\mathrm{CV} \%$} & 5.14 & 4.03 & 3.13 & 4.69 \\
\hline
\end{tabular}

$* *=$ Significant at $1 \%$ level and NS= Non significant level. Means followed by common letter(s) in a column do not differ significantly by DMRT.

\subsection{Rice seedling growth parameters as influenced by variety and seed priming}

There were significant effects of treatments and their interaction on seedling growth parameters (Table 6). The vigor index, shoot and root length and dry weight of seedlings of different tested rice varieties were ranged from 12.2 to $25.08,2.9$ to $11.1,3.5$ to $6.8 \mathrm{~cm}$ and 200 to $373 \mathrm{mg}$, respectively, depending of priming treatments and crop varieties (Table 4, 5 and 6).
3.6. Rice seedling growth parameters as influenced by variety

All the seedling growth parameters due to effect of four rice varieties were presented in Table 4. Among the varieties, the highest vigor index was found in BRRI dhan51 (23.04), BRRI dhan41 (23.5) and BRRI dhan49 (23.6). The highest shoot length was found in Nerica variety (9.8 $\mathrm{cm})$ on $15^{\text {th }}$ day and highest root length was found in BRRI dhan41 $(5.9 \mathrm{~cm})$ on $10^{\text {th }}$ day and BRRI dhan $51(5.9 \mathrm{~cm})$ on $15^{\text {th }}$ day. 


\subsection{Rice seedling growth parameters as influenced by seed priming}

All the seedling growth parameters due to effect of five priming treatments and control were presented in Table 5. The highest vigor index was found in Vitamin C priming (23.9) which is statistically almost similar to Osmo-hardening (22.6). In shoot length, the highest shoot length was observed in Vitamin $\mathrm{C}$ priming and Osmohardening on $10^{\text {th }}$ day and also again Vitamin C priming for shoot length on $15^{\text {th }}$ Day. The maximum dry weight was found in Hardening (319 mg) and Hydro-priming (330 mg).

\subsection{Rice seedling growth parameters as influenced by interaction effect of variety and seed priming}

All the seedling growth parameters due to interaction effect of variety and priming are presented in Table 6 There was significant effect of treatments and their interaction on seedling growth parameters. Statistically, the highest vigor index was found in Nerica variety with Vitamin C priming (23.08) and followed by Osmo-hardening priming (18.5). On-farm priming (13.07), Hardening (12.7) and Hydropriming (12.2) were carried same value compare to control.

Table 4. Effect of variety on rice seedling growth parameters

\begin{tabular}{lcccccc}
\hline \multirow{2}{*}{ Variety } & \multirow{2}{*}{$\begin{array}{c}\text { Vigor } \\
\text { index }\end{array}$} & \multicolumn{2}{c}{ Shoot length $(\mathrm{cm})$ on } & \multicolumn{2}{c}{$\begin{array}{c}\text { Root length }(\mathrm{cm}) \\
\text { on }\end{array}$} & $\begin{array}{c}\text { Seedling dry } \\
\text { weight(mg) } \\
\text { on } 15^{\text {th }} \text { day }\end{array}$ \\
\cline { 3 - 6 } & & $10^{\text {th }}$ day & $15^{\text {th }}$ day & $10^{\text {th }}$ day & $15^{\text {th }}$ day & \\
& $15.6 \mathrm{~b}$ & 5.8 & $9.8 \mathrm{a}$ & $4.9 \mathrm{~b}$ & $4.9 \mathrm{~b}$ & 282 \\
Nerica & $23.04 \mathrm{a}$ & 5.05 & $8.3 \mathrm{bc}$ & $5.2 \mathrm{ab}$ & $5.9 \mathrm{a}$ & 284 \\
BRRI dhan51 & $23.5 \mathrm{a}$ & 6.2 & $9.5 \mathrm{ab}$ & $5.9 \mathrm{a}$ & $5.4 \mathrm{ab}$ & 287 \\
BRRI dhan41 & $23.6 \mathrm{a}$ & 6.4 & $8.02 \mathrm{c}$ & $4.8 \mathrm{~b}$ & $5.2 \mathrm{ab}$ & 274 \\
BRRI dhan49 & $* *$ & $\mathrm{NS}$ & $* *$ & $* *$ & $* *$ & $\mathrm{NS}$ \\
\hline Level of significance & 4.67 & 29.74 & 7.37 & 16.75 & 13.7 & 25.51 \\
CV\% & & & & & &
\end{tabular}

**=Significant at $1 \%$ level and NS= Non significant level. Means followed by common letter(s) in a column do not differ significantly by DMRT.

Table 5. Effect of priming on rice seedling growth parameters

\begin{tabular}{|c|c|c|c|c|c|c|}
\hline \multirow[t]{2}{*}{ Priming } & \multirow{2}{*}{$\begin{array}{l}\text { Vigor } \\
\text { index }\end{array}$} & \multicolumn{2}{|c|}{ Shoot length $(\mathrm{cm})$ on } & \multicolumn{2}{|c|}{$\begin{array}{l}\text { Root length }(\mathrm{cm}) \\
\text { on }\end{array}$} & \multirow{2}{*}{$\begin{array}{l}\text { Seedling dry } \\
\text { weight }(\mathrm{mg}) \\
\text { on } 15^{\text {th }} \text { day }\end{array}$} \\
\hline & & $10^{\text {th }}$ day & $15^{\text {th }}$ day & $10^{\text {th }}$ day & $15^{\text {th }}$ day & \\
\hline Control & $21.2 \mathrm{bc}$ & $4.01 \mathrm{~b}$ & $8.6 \mathrm{bc}$ & 4.6 & $5.6 \mathrm{ab}$ & $239 \mathrm{~b}$ \\
\hline On-farm priming & $20.2 \mathrm{c}$ & $5.04 \mathrm{ab}$ & $8.3 \mathrm{c}$ & 4.8 & $4.9 \mathrm{ab}$ & $293 \mathrm{ab}$ \\
\hline Hardening & $20.8 \mathrm{c}$ & $5.7 \mathrm{ab}$ & $8.3 \mathrm{c}$ & 5.4 & $4.8 \mathrm{~b}$ & $319 \mathrm{a}$ \\
\hline Hydro-priming & $19.8 \mathrm{c}$ & $5.7 \mathrm{ab}$ & $8.8 \mathrm{bc}$ & 5.09 & $5.7 \mathrm{a}$ & $330 \mathrm{a}$ \\
\hline $\begin{array}{l}\text { Osmo-hardening } \\
(\mathrm{NaCl})\end{array}$ & $22.6 \mathrm{ab}$ & $7.2 \mathrm{a}$ & $9.6 \mathrm{ab}$ & 5.5 & $5.6 \mathrm{ab}$ & $253 \mathrm{ab}$ \\
\hline $\begin{array}{l}\text { Vitamin C priming } \\
\text { (Ascorbic Acid) }\end{array}$ & $23.9 \mathrm{a}$ & $7.5 \mathrm{a}$ & $10.02 \mathrm{a}$ & 5.5 & $5.4 \mathrm{ab}$ & $256 \mathrm{ab}$ \\
\hline $\begin{array}{l}\text { Level of } \\
\text { significance }\end{array}$ & $* *$ & $* *$ & $* *$ & NS & $*$ & $* *$ \\
\hline $\mathrm{CV} \%$ & 4.67 & 29.74 & 7.37 & 16.75 & 13.7 & 25.51 \\
\hline
\end{tabular}

**=Significant at $1 \%$ level and NS= Non significant level. Means followed by common letter(s) in a column do not differ significantly by DMRT. 
Table 6. Interaction effect of seed priming and variety on seedling growth parameters of rice

\begin{tabular}{|c|c|c|c|c|c|c|c|}
\hline \multicolumn{2}{|c|}{ Interaction of treatment } & \multirow{2}{*}{$\begin{array}{l}\text { Vigor } \\
\text { index }\end{array}$} & \multicolumn{2}{|c|}{$\begin{array}{l}\text { Shoot length }(\mathrm{cm}) \\
\text { on }\end{array}$} & \multicolumn{2}{|c|}{$\begin{array}{l}\text { Root length }(\mathrm{cm}) \\
\text { on }\end{array}$} & \multirow{2}{*}{$\begin{array}{c}\text { Seedling dry } \\
\text { weight (mg) } \\
\text { on } 15^{\text {th }} \text { day }\end{array}$} \\
\hline Seed priming & Variety & & $\begin{array}{l}10^{\text {th }} \\
\text { day }\end{array}$ & $15^{\text {th }}$ day & $10^{\text {th }}$ day & $\begin{array}{l}15^{\text {th }} \\
\text { day }\end{array}$ & \\
\hline \multirow[t]{4}{*}{ Control } & $\mathrm{V}_{1}$ & $13.9 \mathrm{e}$ & 2.9 & 9.5 a-e & $3.5 \mathrm{e}$ & 4.9 & 203 \\
\hline & $\mathrm{V}_{2}$ & $23.8 \mathrm{ab}$ & 4.0 & $7.9 \mathrm{e}-\mathrm{i}$ & $5.1 \mathrm{~b}-\mathrm{e}$ & 6.8 & 270 \\
\hline & $\mathrm{V}_{3}$ & $23.5 \mathrm{ab}$ & 4.0 & $9.1 \mathrm{~b}-\mathrm{h}$ & $5.5 \mathrm{~b}-\mathrm{d}$ & 5.3 & 257 \\
\hline & $\mathrm{V}_{4}$ & $23.6 \mathrm{ab}$ & 5.1 & $7.6 \mathrm{f}-\mathrm{i}$ & $4.3 \mathrm{c}-\mathrm{e}$ & 5.3 & 227 \\
\hline On-farm & $\mathrm{V}_{1}$ & $13.07 \mathrm{e}$ & 5.5 & $9.8 \mathrm{a}-\mathrm{d}$ & $5.2 \mathrm{~b}-\mathrm{e}$ & 4.65 & 263 \\
\hline \multirow[t]{3}{*}{ priming } & $\mathrm{V}_{2}$ & $20.8 \mathrm{~cd}$ & 4.3 & $7.4 \mathrm{hi}$ & $4.7 \mathrm{~b}-\mathrm{e}$ & 4.9 & 287 \\
\hline & $\mathrm{V}_{3}$ & $23.5 \mathrm{a}-\mathrm{c}$ & 5.3 & $8.5 \mathrm{~d}-\mathrm{i}$ & $4.9 \mathrm{~b}-\mathrm{e}$ & 5.5 & 317 \\
\hline & $\mathrm{V}_{4}$ & $23.6 \mathrm{ab}$ & 5.0 & $7.4 \mathrm{hi}$ & $4.4 \mathrm{c}-\mathrm{e}$ & 4.8 & 307 \\
\hline \multirow{4}{*}{ Hardening } & $\mathrm{V}_{1}$ & $12.7 \mathrm{e}$ & 6.0 & $9.5 \mathrm{a}-\mathrm{f}$ & 4.9 b-e & 4.3 & 353 \\
\hline & $\mathrm{V}_{2}$ & $23.2 \mathrm{a}-\mathrm{c}$ & 3.7 & $7.5 \mathrm{~g}-\mathrm{i}$ & $4.8 \mathrm{~b}-\mathrm{e}$ & 5.8 & 260 \\
\hline & $\mathrm{V}_{3}$ & $23.9 \mathrm{ab}$ & 7.3 & $9.0 \mathrm{c}-\mathrm{h}$ & $7.7 \mathrm{a}$ & 4.7 & 357 \\
\hline & $\mathrm{V}_{4}$ & $23.2 \mathrm{a}-\mathrm{c}$ & 5.7 & $7.03 \mathrm{i}$ & $4.05 \mathrm{de}$ & 4.4 & 307 \\
\hline Hydro- & $\mathrm{V}_{1}$ & $12.2 \mathrm{e}$ & 6.3 & $8.1 \mathrm{~d}-\mathrm{i}$ & $5.3 \mathrm{~b}-\mathrm{e}$ & 5.3 & 330 \\
\hline \multirow[t]{3}{*}{ priming } & $\mathrm{V}_{2}$ & $21.6 \mathrm{bc}$ & 6.0 & $8.2 \mathrm{~d}-\mathrm{i}$ & 4.6 b-e & 5.7 & 357 \\
\hline & $\mathrm{V}_{3}$ & $22.6 \mathrm{a}-\mathrm{c}$ & 4.5 & 9.9 a-d & $5.3 \mathrm{~b}-\mathrm{e}$ & 6.0 & 260 \\
\hline & $\mathrm{V}_{4}$ & $22.7 \mathrm{a}-\mathrm{c}$ & 6.0 & $9.07 \mathrm{c}-\mathrm{h}$ & $5.2 \mathrm{~b}-\mathrm{e}$ & 5.8 & 373 \\
\hline Osmo- & $\mathrm{V}_{1}$ & $18.5 \mathrm{~d}$ & 6.9 & $11.1 \mathrm{a}$ & $5.4 \mathrm{~b}-\mathrm{d}$ & 5.3 & 260 \\
\hline hardening & $\mathrm{V}_{2}$ & $23.8 \mathrm{ab}$ & 6.0 & 9.6 a-e & $5.6 \mathrm{~b}-\mathrm{d}$ & 6.5 & 293 \\
\hline \multirow[t]{2}{*}{ (Nacl) } & $\mathrm{V}_{3}$ & $23.2 \mathrm{a}-\mathrm{c}$ & 7.7 & 9.6 a-e & $6.2 \mathrm{~b}$ & 5.5 & 227 \\
\hline & $\mathrm{V}_{4}$ & $25.07 \mathrm{a}$ & 8.3 & $7.9 \mathrm{ab}$ & $4.9 \mathrm{~b}-\mathrm{e}$ & 5.01 & 230 \\
\hline Vitamin C & $\mathrm{V}_{1}$ & $23.08 \mathrm{a}-\mathrm{c}$ & 7.3 & $10.7 \mathrm{a}-\mathrm{c}$ & $4.7 \mathrm{~b}-\mathrm{e}$ & 4.7 & 250 \\
\hline priming & $\mathrm{V}_{2}$ & $25.08 \mathrm{a}$ & 6.3 & $9.3 \mathrm{~b}-\mathrm{g}$ & $6.09 \mathrm{bc}$ & 5.9 & 237 \\
\hline (Ascorbic & $\mathrm{V}_{3}$ & $23.9 \mathrm{ab}$ & 8.3 & $10.9 \mathrm{ab}$ & $5.7 \mathrm{~b}-\mathrm{d}$ & 5.4 & 307 \\
\hline Acid) & $\mathrm{V}_{4}$ & $23.5 \mathrm{a}-\mathrm{c}$ & 8.0 & $9.1 \mathrm{~b}-\mathrm{h}$ & $5.5 \mathrm{~b}-\mathrm{d}$ & 5.5 & 200 \\
\hline \multicolumn{2}{|c|}{ Level of significance } & $* *$ & NS & $* *$ & $*$ & NS & NS \\
\hline \multicolumn{2}{|c|}{$\mathrm{CV} \%$} & 4.67 & 29.74 & 7.37 & 16.75 & 13.70 & 25.51 \\
\hline
\end{tabular}

*= Significant at 5\% level, **=Significant at 1\% level and NS= Non significant level. Means followed by common letter(s) in a column do not differ significantly by DMRT.

Where, $\mathrm{V}_{1}=$ Nerica, $\mathrm{V}_{2}=$ BRRI dhan51, $\mathrm{V}_{3}=$ BRRI dhan $41, \mathrm{~V}_{4}=$ BRRI dhan 49

Vigor index of BRRI dhan51, BRRI dhan41 and BRRI dhan49 varieties were also observed maximum with Osmo-hardening and Vitamin C priming but, there were no statistical difference with that of control. In shoot length, the highest shoot length was found in Nerica variety with Osmo-hardening priming and followed by Nerica variety with Vitamin $\mathrm{C}$ priming and it was $11.1 \mathrm{~cm}, 10.4 \mathrm{~cm}$ respectively. Burgeieres $e t$ al. (2007) and Barh et al. (2008) reported that Ascorbic acid stimulated the germination percentage, coleoptile percentage, radical length and vigor index of tomato and pea seeds in distilled water medium. These results were in agreement with our findings. In root length, the highest root length was found in BRRI dhan41 with Hardening and followed by BRRI dhan 41 with Osmo-hardening and it was $7.8 \mathrm{~cm}, 6.2 \mathrm{~cm}$, respectively. Our result is in agreement with Ramesh and Singh (2006) who did seed priming in rice with $\mathrm{K}_{2} \mathrm{SO}_{4}$ and ascorbic acid with four rice genotypes (Pusa Basmati-1, Basmati-385, Saket-4 and IR-36) and found seed priming with ascorbic acid was effective in enhancing root and 
shoot length. In dry weight, numerically the highest dry weight was found in BRRI dhan49 (373mg) with Hydro-priming followed by BRRI dhan51 (357 mg) with Hydro-priming and BRRI dhan41 (357 mg) with Hardening. According to Farooq et al. (2007), Hydro-priming for $48 \mathrm{~h}$ improved the growth and dry weight of rice seedlings. If we consider the total effect of seed priming on seedling growth parameters, the results of the present study clearly showed that treatment Vitamin C priming performed very well for Nerica variety. The increase of vigor index might be related to reduction of imbibitions lag time for priming treatment (Bradford, 1986).

Priming also causes physiological and biochemical changes in seed during the seed treatments and metabolic activities increases alpha-amylase activity, thus indicating higher vigor index and well developed shoot and root (Lee and Kim, 2000). Vigor index of seedling is related to germination ability of seeds and nutritional level and those are affected by the many factors, such as moisture, temperature, light, nutrition, pathogen etc. So, there was also large scope to vary the result by applying same treatment in time. Our findings are in agreement with the statement of Mukherjee and Hossin, (2012), Guan et al. (2009) and Rahimi (2013) who found Vitamin C priming can increase growth parameters of seedling.

\section{Conclusions}

It may be concluded that there was significant effect of seed priming on different rice varieties. However, the priming effect differed with rice varieties. The variety Nerica showed poor performance; whereas the other varieties were found superior. Vitamin $\mathrm{C}$ priming and Osmohardening were found superior compared to others priming treatments. Seed germination and seedling growth parameters particularly germination percentages, germination energy, vigor index, shoot and root lengths were increased by the treatments with Vitamin C priming and Osmo-hardening for Nerica. Further investigation may be undertaken to confirm this result and make recommendations on seed priming.

\section{References}

Bam RK., Kumaga FK., Ori., K. Asiedu EA. 2006. Germination, Vigour and Dehydrogenase Activity of Naturally Aged Rice (Oryza sativa L.) Seeds Soaked in Potassium and Phosphorus. Asian Journal of Plant Sciences, 5: 948955.

Basra SMA., Farooq M., Tabassum R. 2005. Physiological and Biochemical Aspects of Seed Vigour Enhancement Treatments in Fine Rice (Oryza sativa L.). Journal of Seed Science Technology, 33(3): 623628.

Basra SMA., Farooq M., Khaliq A. 2003. Comparative Study of Pre-sowing Seed Enhancement Treatments in Fine Rice (Oryza sativa L.). Pakistani Journal of Life Social Science, 1(2): 5-9.

Basra SMA., Farooq M., Wahid A., Khan MB. 2006. Rice Seed Invigoration by Hormonal and Vitamin Priming. Journal of Seed Science Technology, 34(6):753758.

Berchie JN., HK Adu-Dapaah., AA Dankyi., WA Plahar., F. Nelson-Quartey J., Haleegoah JN., Asafu-Agyei JK Ado. 2010. Practices and constraints in bambara groundnuts production, marketing and consumption in the brong ahafo and upper-East Regions of Ghana. Journal of Agronomy, 9: 111-118.

Binang WB., Shiyam JQ., Ntia JD. 2012. Effect of seed priming method on agronomic performances and cost effectiveness of rain fed dry-seeded NERICA rice. Research Journal of Seed Science. 5:136143.

Bradford KJ. 1986. Manipulation of Seed water Relations via Osmotic Priming to Improve 
Germination under Stress Conditions. Journal of horticultural sciences, 21:1105-1112.

Burguieres E., Mccue P., Kwon Y., Shetty K. 2007. Effect of Vitamin C and Folic Acid on Seed Vigor Response and Phenoliclinked Antioxidant Activity. Canadian Journal of Botany, 84:1196-1202.

Farooq M., Basra SMA., Khalid M., Tabassum R., Mehmood T. 2006. Nutrient Homeostasis, Reserves Metabolism and Seedling Vigor as Affected by Seed Priming in Coarse rice, Canadian Journal of Botany, 84:1196-1202.

Ghiyasi M., Seyahjam AA., Tajbakhs M., Amrma R., Salehzade H. 2008. Effect of Osmopriming with Polyethylene Glycol (8000) on Germination and Seedling Growth of Wheat (Triticum aestivum L.)Seeds under Salt Stress. Journal of Biological Science, 3(10):1249-1251.

Gomez AK., Gomez AA. 1984. Statistical Procedures for Agricultural Research 2nd ed. International Rice Research Institute, Los Banos, Philippines, pp 207-215.

Guan Ya. Jing., Jin HU., Wang Xian. JU., Chen Xia. Shao. 2009. Seed Priming with Chitosan Improve Maize Germination and Seedling Growth in Relation to Physiological Changes under Low Temperature Stress. Journal of Zhejiang University of Science, 10(6):427-43.

Harris D., Joshi A., Khan PA., Gothakar P., Sodhi PS. 1999. On-farm Seed Priming in Semi-arid Agriculture: Development and Evaluation in Corn, Rice and Chickpea in India using Participatory Methods. pp. 1529.

Krishnaswamy V., Seshu DV. 1990. Germination after accelerate aging and associated characters in rice varieties. Journal of Seed Science and Technology, 18(1): 147-15.
Lee SS., Kim JH. 2000.Total Sugars, $\alpha$-amylase Activity and Germination after Priming of Normal and Aged Rice Seeds. Korean Journal of Crop Science, 45(3):108-111.

Maguire ID. 1962. Speed of germination aid in selection and evaluation for seedling emergence and vigor. Journal of Crop Science. 2(2): 176-177.

Mohammadi GR. 2009. The effect of seed priming on plant traits of late-spring seeded soybean (Glycine max L.). AmEuras. Journal of Agriculture Environmental Science, 5(3): 322-326.

Mondal BC., Mukherjee T., Mandal L., Evans CJ., Sinenko SA., Martinez-Agosto JA., Banerjee U. 2011. Interaction between differentiating cell- and niche-derived signals in hematopoietic progenitor maintenance. Cell 147:1589-1600. doi: 10.1016/j.cell.2011.11.041.

Rahimi A. 2013. Seed Priming Improves the Germination Performance of Cumin (Cuminum syminum L.) under Temperatures and Water Stress. Journal of Industrial Crops Product, 42:454-460.

Ramesh B., Singh MK. 2006. Effect of Seed Priming with K2SO4 on Germination and Seedling Growth in Rice. Journal of Agricultural Science Digest, 26: 261-264.

Taylor AG., Allen PS., Bennett MA., Bradford JK., Burris JS., Misra MK. 1998. Seed Enhancements. Journal of Seed Science and Technology, 8(2): 245-256.

Yadav VY., Kumari M., Ahmed Z. 2011. Seed Priming Mediated Germination Improvement and Tolerance to Subsequent Exposure to Cold and Salt Stress in Capsicum. Research Journal of Seed Science, 4:125-136. 